\title{
Chinese Cultural Revolution CEO and Earnings Management
}

\author{
Zhao Tianyue \\ Department of Finance, Jinan University, Guangzhou, China 510632 \\ Email: brenda_130163.com
}

\begin{abstract}
There is mounting evidence of the influence of personal characteristics of chief executive officers (CEOs) on corporate governance. This paper analyzed the relation between Chinese Cultural Revolution experience of CEOs (Cultural Revolution CEOs) and corporate earnings management. The research work shows that Chinese Cultural Revolution experience is associated with conservative earnings management behavior taking allowance for corporate ownership structure. Cultural Revolution CEOs pursue less corporate earnings management, especially in terms of negative earnings management, and perform better if their decision-making power is bigger. When real tax rate rises, Cultural Revolution CEOs prevent companies from undertaking aggressive tax-avoiding earnings management and behave more effective if corporate earnings management is severer. The study also shows that CEOs living closer to Chinese politic center in the youth perform better in reducing corporate earnings management. Taken together, the results show that Chinese Cultural Revolution experience of CEOs has significant explanatory power for earnings management decisions.
\end{abstract}

Keywords: Earnings management; Chinese Cultural Revolution; CEO

\section{Introduction}

Earnings management is critical for accounting information quality as it may deteriorate financial statements if aggressively used. It has always been a topic focused by investors and executives because firms undertaking earnings management can mislead market participants resulting in investors interests loss and capital resources improperly allocated. According to upper echelons theory, preferences and attitudes of top managers toward earnings management decide corporate behaviors (Chatterjee, Hambrick, 2007; Hambrick, 2007). There is mounting evidence of the influence of personal characteristics of chief executive officers (CEOs) on corporate governance (Bertrand, Schoar, 2003).

Studies related to life course theory have proved that personal experiences significantly affect individual behaviors in long terms (Main et al, 1985; Kendler et al, 2002). Malmendier et al (2011) pioneered the idea of studying influence of personal experiences on corporate finance and found that Great Depression and military backgrounds significantly affected manager decision-making behaviors. It has been proved that suffering from civil unrest will magnify people inside feelings of insecurity and uncertainty, hence influence individual cognitive toward risks and decision-making preferences (Shi Kan, 2010). For chief executive officers (CEOs), it may further affect corporate governance and corporate behaviors. Since 2007 global financial crisis, numerous social disruption and terrorist events have burst around the world, which are disturbing and terrifying people worldwide. Noticeably, younger generation is one of the most destructive strength launching and encouraging social disruptions (Zheng Danniang, Zhang Sumin, 2012), so it is of great value to find out the long-term influence of social unstable events on younger generation's future development.

Despite all this attention to corporate governance and CEO characteristics, little research has attempted to explore the potential relation between social disruption experiences of CEO in the youth and corporate earnings management. Events in which people suffered or witnessed deadly threats of his or other peoples' lives and felt extremely terrified and insecure are most likely developed into traumatic experiences. In that case, suffering from social disruptions and terroristic events to great extend will develop into psychic traumas (Davis, Siegel, 2000). Actually, Chinese Cultural Revolution is a typical social unrest period that may cause psychic traumas and there is even trauma literature derived from it. Studies about influence of CEO Cultural Revolution experience on corporate governance are rare, so we aim to provide empirical evidence by focusing on the relation between CEOs with Cultural Revolution experiences (Cultural Revolution CEOs) and corporate earning management behaviors. 
Chinese Cultural Revolution took place between mid-1960s and mid-1970s causing the generation irreconcilable long-term trauma. Up to $50 \%$ of CEOs of Chinese listed companies are in their 40s that matches age of the generation suffered from Cultural Revolution period. Since trauma experiences may shape individual decision-making behaviors by affecting their cognitive toward risks, it is of great value studying relation between Cultural Revolution CEO and corporate earning management behaviors.

This study tries to find out if there are differences between Cultural Revolution CEOs and non-Cultural Revolution CEOs on earning management decisions and if Cultural Revolution CEO risk preferences are affected by corporate equity structure, earnings management purposes and degrees and the mechanism of Cultural Revolution CEOs being influenced. By constructing CEO - year data set and employing fixed effect panel models, the research acquires findings using generalized least squares (GLS) method and find that firms run by Cultural Revolution CEOs will undertake less earnings management. The results show that earnings management of state-owned firms and firms with bigger director board, higher proportion of independent directors and more concentrated ownerships is more likely to be negatively affected by Cultural Revolution CEOs. The findings are also suggestive of an association between Cultural Revolution CEOs and more conservative negative earnings management especially when it is for tax-avoiding purposes. It may explain the reason why when real tax rate increases, corporate earnings management tends not to increase significantly.

CEOs who lived closer to politic center in the youth during Cultural Revolution period will be more conservative toward earning management. Noticeably, CEOs who turned into 13 or 14 years old between 1973 and 1976 which was the third period of Cultural Revolution when steady and practical policy was praised prefer more conservative earnings management than their counterparties. In the robustness checks part, the research excludes possible concern of CEO aging factor, adverse selection and endogenous problem. The study as well employs differences in difference method to analyze the effect of Cultural Revolution CEOs transformation on corporate earnings management. Results show that firms run by Cultural Revolution CEOs not only perform less earnings management, but will increase after Cultural Revolution CEOs leave their posts and the increase trend is persistent in a longer term.

These findings make two primary contributions to our understanding of internal governance. First, they reveal that social disruptions experiences that may cause psychic trauma, taking Chinese Cultural Revolution as a typical example, will affect CEOs' decision-making preference. The findings enrich the application of life course theory in behavioral economics and provide empirical evidence based on Chinese typical events. Second, it is the first time to systematically discuss the influence of CEOs' Chinese Cultural Revolution experiences on their attitudes toward earnings management and further on firms' behaviors. Since almost $50 \%$ of Chinese listed companies' CEOs have suffered from Chinese typical events, our findings are of great value in terms of understanding patterns of Chinese listed firms' earnings management.

\section{CEOs with Cultural Revolution Experience and Corporate Earnings Management}

\subsection{Influence of Chinese Cultural Revolution on Contemporary Youth}

From the aspect of sociology, adolescents take part in social unrest events to aggressively express themselves because they are one of the most vulnerable and isolated group in the society(Lin Kuangzheng, 2010). Being lost in acquiring culture and identification recognition, adolescents show more sensibility than other age groups and react more intensively to social disruption(Li Chunli, 2012). Despite the flexibility and formability, young people are susceptible to emerging and leading-edge trends and phenomenon so their actions are pioneering. The vanguard character can be easily observed not only in American historical events like the 60s-70s civil rights movement, the hippie movement, the anti-war movement, but also in Chinese revolutionary events like the May Fourth movement and the Cultural Revolution. Values of the youth are two-sided with both positive and negative aspect and they are expressed differently according to social transitions. Young people are liable to behave positively and optimistically if social changes are mild while become more critical, negative and pessimistic if they experienced society upheavals or revolutionary political changes(Richard, 1989; Liao Xiaoping, Chen Jianyue, 2006).

There are various trends of thoughts affecting people's speech and behavior during the period of Cultural 
Revolution, typically, some of which praised class struggle, utopian socialism, hero worship and nihilism. Under the "left" trends, individual thoughts were numb and ossification while interpersonal conflicts were intense and acute (Wong Youwei, 1997). As a result, experiencing conflicts of survival and development such as crisis of trust and confusion of life value, young generation of the mid-1960s and mid-1970s tend to distrust community and live aimless lives. Feeling perplexed, pessimistic, suspicious and rebellious most of the young people from Cultural Revolution grew up with painful regrets and disappointments (Zhejiang youth league school research group, 2004). Because of the campaigns and political battles, school education was suspended and adolescents that should be school educated then were sent to countryside to be "reeducated". By the time when Cultural Revolution was over, great amount of urban young people had already lived in countryside for years and they came back to the city engaging in the reform and openness era straight after. A survey about purposes of each generation attending adult education in Shanghai shows that people in the 40-60 group which is at same time the Cultural Revolution generation attend adult education mainly for purposes of family harmony, social life stimulation, cognitive interests and social interactions, which reveals the fact that this group of people are the most stressed and overwhelmed ones in the fierce competition nowadays (Boshier R, Yan Huang et al, 2006). From the above, the study makes an assumption that after experiencing the upheaval of social transformation, frustrations of disillusionment and disappointments of trust crisis, the Cultural Revolution generation are more likely to form conservative and prudent decision-making preferences and be evasive and aversive toward risks in nowadays fiercely competitive development.

\subsection{Traumatic Experiences Affect Individual's Decision Making}

Confirmation of psychic trauma has two requisite factors: firstly, individuals experienced, witnessed or suffered events that caused victims severe injuries or dreadfully threatened others' lives; secondly, victims felt extremely terrified, helpless and desperate during the event. It is known that victims of disasters, witnesses of death and severe injuries are most likely to be traumatized (Davis, Siegel, 2000). Furthermore, psychic traumas caused by dreadful events may develop into post-traumatic stress disorder (PTSD). According to biology, psychic trauma may trigger neurochemical response in long term especially when patients are under pressures (Davis, Siegel, 2000). Psychological researches find that individual early experiences are closely related to adult behavior and may affect it in long term (Li Ting, Zhu Xiongzhao, 2009). Van der Kolk (1995) believed that victims with psychic traumas may unconsciously bring the unpleasant into daily lives and are liable to feel anxious. Adverse experiences in early life may result in an adult with lack of independence, difficulty to trust, trouble in building healthy interpersonal relationships and vulnerability to negative emotions like self-abasement (Main et al, 1985). Shi Kan and et al (2010) also find that when people are experiencing massive changes of circumstances, trauma victims may recall the traumatic events because of pressures from disruptive surroundings. Major events with long-term repeated influences on victims will enhance sufferer's feelings of insecurity and uncertainty of the future, affect victim's emotional and intellectual conditions, alter their cognitions of risks and ultimately determine individual decision-making processes and actual behaviors (Covello et al, 2001). Youth is the most sensitive and critical time of preference formation, so it will impose long-term effects on individual risk preference and decision making if a person experienced major social events like economic system reformation and political structure alternative in the youth (Krosnick, Jon A and et al, 1989; Alberto Alesina, 2005). It is also proved that the macro-economic situation when a person first entry into labor market will impose sustainable influences on his behaviors.

\subsection{Early Experiences Affect Investors' Risk References}

Experiencing different macro-economic circumstances will affect investors' long-term risk preferences. Specifically, suffering from stock market downturn investors tend to be conservative and cautious toward financial risks and be pessimistic toward stock yields in the future (Malmendier, 2011). The return rates of security portfolios in the past will affect investors' choices of investment portfolio in the future because instead of making progresses through rational Bayesian learning process, investors tend to emphasize personal investment experiences (Markku kaustia et al, 2008). Tracing back to early growth paths of investors, researchers find that birth weight and growing-up environment may help to determine risk tolerance of investors (Henrik Cronqvist et al, 2015). About the relations between individual growth paths 
and their political attitudes, studies have proved that macro-economic environment will affect people's redistribution preferences. Suffering from economic recessions in the youth may cause people to believe that success depends more on luck but not efforts, so they tend to support government aggressive redistribution policies and the left parties and the influences seem to be persistent (Paola Giuliano, 2014).

\subsection{CEO's Early Experiences Affect Corporate Financial Structure and Firm's Performance}

When it comes to a CEO, his sufferance from massive social unrest in youth may affect his decision-making behaviors which will further determine corporate management styles especially for financial policies and investment behaviors. Danthine and et al (1990) find that an American CEO's adolescent experience of the Great Depression in 1930s imposes long-term influence on the CEO's management risk preference. Graham and et al (2004) show that companies with higher debt ratio and lower bond rating are more liable to be trapped into financial distress during the Great Depression and CEOs of these companies will remain the preference of less debt financing even when economic conditions are improved. The above conclusion is widely proved (Malmendier et al, 2011). It is revealed that differences of CEO management styles are determined by economic conditions of the time when a CEO first enters labor markets. Entering the labor market in economic recessions makes CEOs to be more conservative who prefer more capital investment, less $\mathrm{R} \& \mathrm{D}$ investment, more restrict cost control, lower operating leverage and milder tax avoidance behavior. It is found that stock of these companies tend to be less volatile as well (Schoar, 2007; Luo Zuo, 2011). As for military CEOs, military experiences promote them to undertake more aggressive management policies, exhibit higher level of risk tolerance and use higher financial leverage (Malmendier et al, 2011). Personal characteristics like level of education, tenure and gender are all factors influencing CEO management risk preferences (Irene Wei Kiong, Ting, 2015). Studies about Chinese listed companies show that managers suffered from the Great Famine in 1959-1961 seem to choose more conservative and passive liability policies (Zhao Minwei, An Yanyang, 2015), and these companies on average invest less and have lower investment efficiency (Shen Weitao, Xing Xiaoyu, 2014). However, literatures do not come to a cohesive conclusion about the diverse effects CEO experiences impose on state-owned and none state-owned companies.

\subsection{CEO Characteristics and Corporate Equity Structure Affect Corporate Earnings Management}

Corporate accounting earnings quality is one of the most focused topics by investors, managers and supervisors. The more shares hold by a CEO, the more likely that he will manipulate stock prices by undertaking earnings management before selling the shares in order to maximize personal interests ( $\mathrm{Su}$ dongwei, Lin dapang, 2010; Beneish ,Vargus, 2002). From the aspect of corporate operating autonomy, researchers find that CEOs enjoying higher level of decision-making rights outside the companies acquire more autonomy as well in terms of corporate management (Karpoff and et al, 2008). Abundant operating autonomy may promote CEO's earnings management decision makings. For Chinese listed companies, $\mathrm{CEO}$ rights and influences are positively related to corporate earnings management and the correlations are more significant under uncertain circumstances (Ye Shengwen, Ye Wangchunzi, 2014). Centralized control rights allow CEOs to better exploit inside resources of companies to improve internal governance and further efficiently affect accounting earnings information quality (He Fan et al, 2015). Supervision from institutional investors can effectively inhibit corporate earnings management, but CEO political correlation significantly weakens the inhibitory effect (Luo Jinbo, 2016). CEO characteristics also influence corporate earnings management; for example, over-confident CEOs tend to undertake risky programs and investments which may motivate companies to manage earnings (Antoinette Rijsenbilt et al, 2013). It has been observed that CEOs are tempted to manage earnings at the beginning of their tenures or in the final year of the tenure while an adequate internal control system can inhibit earnings management (Ashiq Ali, Weining Zhang, 2014). CEOs with experiences in financing and management are less likely to manage earnings aggressively (Jiang Fuxiu et al, 2013). Firms that have forced CEO turnovers are liable to have severer earnings management indicating that boards tend to act proactively to discipline managers who manage earnings aggressively (Sonali Hazarika et al, 2012).

Corporate equity structure affects correlations of CEO experiences and corporate earnings management too. On the one hand, state-owned companies have much more limited operating autonomies than 
non-state-owned ones, which result in more government interferences on financial decision makings of state-owned corporates (Li Peigong, Xiao Min, 2012). In that case, CEO experiences and characteristics may affect corporate behaviors less effectively (Chen Yanyan, Luo Danglun, 2012). On the other hand, there are considerable amount of Chinese listed companies owned by state institutions and CEOs of these companies are responsible only for the biggest state shareholders instead of minority shareholders, so these CEOs may perform earnings management more aggressively for their own interests (Su Dongwei, Lin Dapang, 2010). Characteristics of board structure like scale of board, independent director ratio and internal directors shareholding ratio all can affect corporate earnings management during CEO transition periods (Zhang Yijie et al, 2006; Liao Puming, 2011).

\subsection{Hypothesis}

Experiencing Chinese Cultural Revolution in the youth, Cultural Revolution CEOs grew up in disruptive circumstances and economic downturns and were exposed to disturbing events that caused social unrests in the most sensitive period of their lives. Affected by society upheavals and major political events, adolescents may form suspicious and negative life values leading to conservative and cautious decision-making preferences (Richard, 1989; Liao Xiaoping, Chen Jianyue, 2006). The generation of Chinese Cultural Revolution, after being overwhelmed by society transformations, deprived of education opportunities, confused by disillusionment of dreams and hurt by trust crisis, were caught up in the wave of Chinese economic reform as soon as they enter into adulthood and could well treat risks with excessive caution and aversion. Firms run by CEOs from this generation may well be characterized by conservative and prudent risk preference and low earnings management level. As a result, it is likely that companies run by Cultural Revolution CEOs tend to undertake less earnings management. Earnings management of state-owned companies will be more obviously inhibited by Cultural Revolution CEOs. Companies with lager board, lower ratio of independent directors and higher ratio of concentration are more likely to be influenced by the conservative preferences of Cultural Revolution CEOs. It is because that the principal-agent problem mainly comes from conflicts among shareholders, making supervisions of executives by shareholders a more inferior problem, and that gives CEOs more autonomies affecting accounting information quality. When a corporate manages earnings too aggressively, its CEO may have so limited influence on corporate behaviors that his risk preference cannot affect corporate earnings management efficiently. It is understandable that only when a company manages earnings within reasons, a Cultural Revolution CEO has available autonomies to significantly inhibit corporate earnings management. When it comes to different involvement degrees and revolution stages that a CEO experienced, the research assumes that the greater a CEO was affected by Cultural Revolution in the youth, the more influence he will impose on corporate earnings management and CEOs experiencing different stage of the revolution will show different attitudes toward corporate earnings management.

From the above, the study comes up with the following hypothesis about the correlation of a Cultural Revolution CEO and corporate earnings management.

H1: CEOs with Chinese Cultural Revolution experiences will inhibit corporate earnings management.

H2: Earnings management of state-owned companies will be more obviously inhibited by Cultural Revolution CEOs.

H3: Companies with less supervision on CEOs empowering a CEO more autonomies to affect accounting earnings quality are well be influenced by Cultural Revolution CEOs' conservative decision-making preferences.

\section{Data and Summary Statistics}

To determine whether the Cultural Revolution experience affects CEO performance, the research constructs a manager-firm matched panel data set. The study starts with data from the CSMAR data base, company annual reports and CEO resumes for 2005-2014. After eliminating statistics of samples that CEO tenures are less than 2 years, companies from financial sector, years with inaccessible CEO information and major accounting information, the study ultimately acquires 8490 manager- firm year data.

The statistical approach in measuring and decomposing accruals to obtain index of corporate earnings management degree is based on adjusted Jones method in Dechow (1995). The research uses following 
models to evaluate company earnings managements.

$$
\begin{aligned}
& T A_{1} / \text { Asset }_{t-1}=\alpha_{1}\left(1 / \text { Asset }_{t-1}\right)+{ }_{2} \Delta R E V_{t} / \text { Asset }_{t-1}+{ }_{3} P P E_{t} / A s s t_{t-1}+\varepsilon \\
& E M=T A_{1} / \text { Asset }_{t-1}-\left[\hat{\alpha}_{1}\left(1 / \text { Asset }_{t-1}\right)+\hat{\alpha}_{2}\left(\Delta R E V_{t}-\Delta R E C_{t}\right) /{ }_{A s s t_{t-1}}+\hat{\alpha}_{3} P P E_{t} / A_{\text {Asset }}\right]
\end{aligned}
$$

Total accruals (TA) is defined as differences between operating profit and net cash flows. $\triangle R E V$ and $\triangle R E C$ respectively indicate growth of operating income and growth of account receivables. PPE represents fixes assets. The study uses absolute value of discretionary accruals (absEM) to indicate corporate earnings management degree according to Liu Huilong (2014) where higher numbers would indicate greater management levels.

To identify CEOs who experienced Cultural Revolution in the youth, this study takes allowance of the fact that psychological studies on children and adolescent's traumatic experiences are usually focused on the age range of two to fifteen. Since Chinese Cultural Revolution took place in 1966 and last for 10 years ending in 1976, following Malmendier (2011) 's definition of Great Depression experience this study identifies CEOs who born between 1952 to 1963 which is 14 years before the beginning of Cultural Revolution and 13 years before its end as CEOs who experienced Cultural Revolution in the youth. This definition aims to guarantee that CEOs who witnessed the 10-year Cultural Revolution since they were 13 or 14 years old are included in experimental group. The major dummy variable (CR) is assigned the value 1 if a CEO's birth year is in the range of 1952 to 1963 and 0 if otherwise.

To eliminate disturbance of abnormal values, the study winsorizes all continuous variables by $5 \%$ and acquires summary statistics showed in table 1 . The statistical summary shows that the average age of CEOs we study is about 47 years old and the spans are large. The mean value of CR variable is 0.49 indicating that almost half of CEOs of Chinese listed companies in our samples have experienced the Cultural Revolution, so it is of great importance to explore if there is certain correlation between CEO CR experiences and their decision-making preferences.

Sample based on all executives is from the cohorts 2005-2014. CEO personal information is from company annual reports and CEO resumes from the CSMAR data base. Statistics for ROA, Book Leverage, Tobin's Q and company structure are from the CSMAR data base and restricted to nonfinancial industries.

Table 1. Summary statistics of full sample

\begin{tabular}{lclllll}
\hline Variable & N & Mean & SD & Median & Min & Max \\
CEO personal characteristics & & & & & \\
\hline gender & 8490 & 0.950 & 0.210 & 1 & 0 & 1 \\
age & 8490 & 46.78 & 6.330 & 46 & 24 & 76 \\
Cultural Revolution & 8490 & 0.490 & 0.500 & 0 & 0 & 1 \\
politic & 8490 & 0.0900 & 0.290 & 0 & 0 & 1 \\
graduate area & 2801 & 2.580 & 1.250 & 2 & 1 & 5 \\
firm characteristics & & & & & & \\
absEM & 8490 & 0.0600 & 0.0500 & 0.0400 & 0 & 0.210 \\
ROA & 8490 & 0.0400 & 0.0500 & 0.0300 & -0.0600 & 0.130 \\
LEV & 8490 & 0.480 & 0.200 & 0.500 & 0 & 0.800 \\
tobin's q & 8490 & 2.200 & 1.300 & 1.780 & 0 & 5.580 \\
size & 8490 & 21.64 & 1.170 & 21.62 & 10.84 & 23.65 \\
board size & 8490 & 2.180 & 0.300 & 2.200 & 0 & 2.890 \\
independent director & 8490 & 0.360 & 0.0600 & 0.330 & 0 & 0.800 \\
equity concentration & 8490 & 36.72 & 15.63 & 34.74 & 0.820 & 89.41 \\
Director \& CEO & 8490 & 1.810 & 0.490 & 2 & 0 & 2 \\
state-owned & 8490 & 0.390 & 0.490 & 0 & 0 & 1 \\
\hline
\end{tabular}

Based on existed literatures, the study uses fixed effect panel data model as followed.

$$
y_{i, t}=\alpha_{0}+\alpha^{*} c r_{j}+\beta^{*} \text { Charateristics }_{j, t}+\delta^{*} X_{i, t}+v_{t}+v_{\text {sector }}+\varepsilon_{i, t}
$$


As the above mentioned, absEM variable representing corporate earnings management level is the major explained variable $\left(y_{i, t}\right) . X_{i, t}$ is control variable of corporate characteristics including firm scale (Size), tobin's Q, return of assets (ROA), leverage (LEV), equity concentration (ECI), ratio of independent directors (INDEPEN), board scale (Board), if a CEO is a member of board at the same time (DIRECEO) and if a company is state-owned (STATEOWN). Charateristics ${ }_{j, t}$ is control variable of CEO personal characteristics including gender (Gender), areas of CEO graduate college (GA) and CEO political backgrounds (Politic). All models control for industry fixed effect and year fixed effect and robust standard error is used to estimate significance of all coefficients. The coefficient of $\mathrm{CR}$ variable $(\alpha)$ indicates correlation between Cultural Revolution experiences and corporate earnings management.

\section{CR CEOs and Corporate Earnings Management}

\subsection{Effects of Cultural Revolution Experience on Firm Earnings Management Behavior}

The research first performed regression of basic fixed-effect panel model as mentioned using full sample and then successively added control variables of CEO political backgrounds and company state-ownerships into the model. Table 2 displayed the results from estimating the above basic regressions. Column 1 of Table 2 studied the correlation between CR experience and corporate earnings management. Similar to literatures about CEO experiences and firm outcomes (Efraim Benmelech, 2015), we controlled for a measure of Tobin's Q, size, ROA, leverage, CEO gender as well as board size, equity concentration, ratio of independent directors, CEO served as director at the same time and industry fixed effect, year fixed effect. The sample size was 8490 firm-year observations. Result showed that the coefficient of CR variable was significantly negative, which mean that CEO Cultural Revolution experience negatively affected corporate earnings management which was consistent with our first hypothesis.

One of the omitted CEO characteristics driving correlations between CEO Cultural Revolution experience and earnings management is CEO political background. CEOs with political correlations are well to take full advantage of the resources to undertake risky chances maximizing corporate profit. It is an important concern that CEO political background may affect corporate earnings management, so we added control variable (Politic) to separate the effect of CEO CR experience from CEO political background effect. To obtain CEO political background data, we manually abstracted information about whether a CEO served as either a NPC (the National People's Congress) representative, a CPPCC (Chinese People's Political Consultative Conference) member, a cadre of government unit, a mayor or a position of similar levels. If it was so, we assigned value 1 to the dummy variable (Politic) and value 0 if otherwise. Column 1 of Table 2 showed result of further regression and the coefficient of CR variable remained robustly negative indicating that conclusion of inhibit effect CR CEOs impose on corporate earnings management still hold up.

CEOs of Chinese listed companies owned by state institutions are responsible only for the biggest state shareholders instead of the minority, so these CEOs may perform earnings management more aggressively for their own interests (Su Dongwei, Lin Dapang, 2010). Earnings management of state-owned companies may be more obviously inhibited by Cultural Revolution CEOs because in state-owned companies, not only Cultural Revolution CEOs are less supervised by internal and external shareholders, but these companies averagely have more earnings management so Cultural Revolution CEO's conservative risk preference can affect corporate behavior more obviously. We hence included dummy variable (STATEOWN) indicating company state ownerships and further added interactions (CR*STATEOWN) into regressions. Column 3, 4 of Table 2 expressed results of updated regressions. The coefficient of CR variable in column 3 was robust indicating that after taking allowance of state ownerships CEO Cultural Revolution experience still has inhibit effects on corporate earnings management. From column 4 we found that coefficient of interaction variable $\left(\mathrm{CR}^{*} \mathrm{STATEOWN}\right)$ was significantly negative and the coefficient of CR variable was negative as well, which indicated that state-owned companies are more obviously effected by cautious decision-making preference of Cultural Revolution CEOs and are liable to have lower level of earnings management. 
Table 2. Effects of Cultural Revolution experience on firm earnings management behavior

\begin{tabular}{|c|c|c|c|c|}
\hline & $\begin{array}{l}\text { absEM } \\
\text { (1) }\end{array}$ & $\begin{array}{l}\text { absEM } \\
(2)\end{array}$ & $\begin{array}{c}\text { absEM } \\
(3)\end{array}$ & $\begin{array}{c}\text { absEM } \\
(4)\end{array}$ \\
\hline $\mathrm{CR}$ & $\begin{array}{l}-0.005^{*} \\
(-1.65)\end{array}$ & $\begin{array}{l}-0.005^{*} \\
(-1.66)\end{array}$ & $\begin{array}{l}-0.005^{*} \\
(-1.70)\end{array}$ & $\begin{array}{l}-0.002 \\
(-0.55)\end{array}$ \\
\hline Politic & & $\begin{array}{l}0.004 \\
(0.95)\end{array}$ & $\begin{array}{l}0.004 \\
(0.97)\end{array}$ & $\begin{array}{l}0.004 \\
(0.94)\end{array}$ \\
\hline STATEOWN & & & $\begin{array}{l}0.003 \\
(1.24)\end{array}$ & $\begin{array}{l}0.007^{* *} \\
(2.18)\end{array}$ \\
\hline c.CR\#c.STATEOWN & & & & $\begin{array}{l}-0.007^{*} \\
(-1.72)\end{array}$ \\
\hline Gender & $\begin{array}{l}-0.006 \\
(-0.86)\end{array}$ & $\begin{array}{l}-0.006 \\
(-0.83)\end{array}$ & $\begin{array}{l}-0.006 \\
(-0.84)\end{array}$ & $\begin{array}{l}-0.006 \\
(-0.81)\end{array}$ \\
\hline Size & $\begin{array}{l}-0.001 \\
(-0.47)\end{array}$ & $\begin{array}{l}-0.001 \\
(-0.47)\end{array}$ & $\begin{array}{l}-0.002 \\
(-0.50)\end{array}$ & $\begin{array}{l}-0.002 \\
(-0.51)\end{array}$ \\
\hline Q & $\begin{array}{l}0.002^{*} \\
(1.73)\end{array}$ & $\begin{array}{l}0.002^{*} \\
(1.75)\end{array}$ & $\begin{array}{l}0.002^{*} \\
(1.73)\end{array}$ & $\begin{array}{l}0.002^{*} \\
(1.71)\end{array}$ \\
\hline ROA & $\begin{array}{l}0.084^{* *} \\
(2.52)\end{array}$ & $\begin{array}{l}0.084^{* *} \\
(2.51)\end{array}$ & $\begin{array}{l}0.084^{* *} \\
(2.51)\end{array}$ & $\begin{array}{l}0.084^{* *} \\
(2.51)\end{array}$ \\
\hline LEV & $\begin{array}{l}0.046^{* * *} \\
(5.18)\end{array}$ & $\begin{array}{l}0.046^{* * *} \\
(5.21)\end{array}$ & $\begin{array}{l}0.047^{* * *} \\
(5.28)\end{array}$ & $\begin{array}{l}0.047^{* * *} \\
(5.26)\end{array}$ \\
\hline ECI & $\begin{array}{l}0.000 \\
(1.48)\end{array}$ & $\begin{array}{l}0.000 \\
(1.47)\end{array}$ & $\begin{array}{l}0.000 \\
(1.37)\end{array}$ & $\begin{array}{l}0.000 \\
(1.36)\end{array}$ \\
\hline INDEPEN & $\begin{array}{l}-0.040^{*} \\
(-1.89)\end{array}$ & $\begin{array}{l}-0.040^{*} \\
(-1.89)\end{array}$ & $\begin{array}{l}-0.039 * \\
(-1.85)\end{array}$ & $\begin{array}{l}-0.039^{*} \\
(-1.86)\end{array}$ \\
\hline DIRECEO & $\begin{array}{l}-0.001 \\
(-0.71)\end{array}$ & $\begin{array}{l}-0.001 \\
(-0.60)\end{array}$ & $\begin{array}{l}-0.001 \\
(-0.58)\end{array}$ & $\begin{array}{l}-0.001 \\
(-0.54)\end{array}$ \\
\hline Board & $\begin{array}{l}-0.002 \\
(-0.42)\end{array}$ & $\begin{array}{l}-0.002 \\
(-0.42)\end{array}$ & $\begin{array}{l}-0.002 \\
(-0.44)\end{array}$ & $\begin{array}{l}-0.002 \\
(-0.44)\end{array}$ \\
\hline Year & Yes & Yes & Yes & Yes \\
\hline Industry & Yes & Yes & Yes & Yes \\
\hline _cons & $\begin{array}{l}0.089 \\
(1.33)\end{array}$ & $\begin{array}{l}0.088 \\
(1.33)\end{array}$ & $\begin{array}{l}0.089 \\
(1.33)\end{array}$ & $\begin{array}{l}0.088 \\
(1.31)\end{array}$ \\
\hline $\mathrm{N}$ & 8490 & 8490 & 8490 & 8490 \\
\hline $\mathrm{r} 2$ & 0.040 & 0.040 & 0.040 & 0.040 \\
\hline
\end{tabular}

* Indicates significance at 10\%; ** significant at 5\%; *** significant at 1\%. Field survey, 2017

CR was an indicator variable for whether the CEO of the firm in the given year had Cultural Revolution experience. All regressions included controls for CEO gender, firm size, Tobin's Q, ROA, leverage, equity concentration, ratio of independent directors, board scale and if a CEO was a member of board at the same time. Regression (2) to (4) included a dummy variable for CEO political backgrounds. Regression (3) and (4) included a dummy variable for whether a company was state-owned and the interaction variable. Robust standard errors in parentheses were clustered by firm.

\subsection{Effects of Board Characteristics on the Correlation Between CEO Cultural Revolution Experience and Corporate Earnings Management}

4.2.1 Board size affects the correlation between CEO Cultural Revolution experience and corporate earnings management

In corporate governance system, director of board aims to alleviate the principal-agent cost which comes from the separation of ownership and management. In some cases, the board may be too big to promptly deliver massages inducing inefficiency and inadequate supervision and under the circumstances a CEO has greater motivation and lower cost to manage earnings, so firms with bigger director of boards are apt to aggressively manage earnings (Zhang Guohua, Chen Fangzheng, 2006). It is convincing that under the 
circumstance where supervision of the board is poor leading to more corporate management and greater CEO decision-making autonomy will empower Cultural Revolution CEO to notably decrease company earnings management. We divided full sample into two subsamples according to board size and named subsamples as Group_board=0,1 in ascending order. Results of grouping regressions were showed in Table 3. It can be found that only coefficient of $\mathrm{CR}$ variable in Group_board=1 was negatively robust indicating that companies with lager boards are more sensible to CEO Cultural Revolution experiences and the inhibit effect is more significant on these companies.

Table 3. Board size affects the correlation between CEO Cultural Revolution experience and corporate earnings management

\begin{tabular}{|c|c|c|}
\hline & $\begin{array}{l}\text { absEM } \\
\text { Group_board }=0 \\
\text { (1) }\end{array}$ & $\begin{array}{l}\text { absEM } \\
\text { Group_ board }=1 \\
(2)\end{array}$ \\
\hline $\mathrm{CR}$ & $\begin{array}{l}-0.003 \\
(-0.41)\end{array}$ & $\begin{array}{l}-0.005^{*} \\
(-1.70)\end{array}$ \\
\hline Gender & $\begin{array}{l}0.028^{* *} \\
(2.02)\end{array}$ & $\begin{array}{l}-0.013^{*} \\
(-1.67)\end{array}$ \\
\hline Size & $\begin{array}{l}0.004 \\
(0.47)\end{array}$ & $\begin{array}{l}-0.002 \\
(-0.60)\end{array}$ \\
\hline Q & $\begin{array}{l}0.002 \\
(0.56)\end{array}$ & $\begin{array}{l}0.003^{* *} \\
(2.00)\end{array}$ \\
\hline ROA & $\begin{array}{l}0.190^{* * *} \\
(2.73)\end{array}$ & $\begin{array}{l}0.040 \\
(1.17)\end{array}$ \\
\hline LEV & $\begin{array}{l}0.055^{* *} \\
(2.46)\end{array}$ & $\begin{array}{l}0.040^{* * *} \\
(3.94)\end{array}$ \\
\hline ECI & $\begin{array}{l}0.000 \\
(0.44)\end{array}$ & $\begin{array}{l}0.000 \\
(0.85)\end{array}$ \\
\hline INDEPEN & $\begin{array}{l}-0.029 \\
(-0.62)\end{array}$ & $\begin{array}{l}-0.025 \\
(-0.83)\end{array}$ \\
\hline DIRECEO & $\begin{array}{l}-0.001 \\
(-0.16)\end{array}$ & $\begin{array}{l}-0.001 \\
(-0.24)\end{array}$ \\
\hline Board & $\begin{array}{l}0.007 \\
(0.58)\end{array}$ & $\begin{array}{l}0.002 \\
(0.15)\end{array}$ \\
\hline Year & Yes & Yes \\
\hline Industry & Yes & Yes \\
\hline _cons & $\begin{array}{l}-0.110 \\
(-0.56)\end{array}$ & $\begin{array}{l}0.096 \\
(1.22)\end{array}$ \\
\hline $\mathrm{N}$ & 2019 & 6471 \\
\hline Within r2 & 0.064 & 0.035 \\
\hline
\end{tabular}

The research divided full sample into two subsamples according to board size and named subsamples as Group_board=0,1 in ascending order. Column 2 was sample with larger board size. All regressions included controls for CEO gender, firm size, Tobin's Q, ROA, leverage, equity concentration, ratio of independent directors, board scale and if a CEO is a member of board at the same time. Robust standard errors in parentheses were clustered by firm.

\subsubsection{Ratio of independent directors affects the correlation between CEO Cultural Revolution experience and corporate earnings management}

Internal directors serving as top managers have access to abundant inside information which allows them to not only better govern executives, but also easily manipulate them to act on behalf of major shareholders and ignore interests of the minority. On the contrary, outside directors are able to supervise managers independently and remarkably alleviate the principal-agent problem. It is proved that more independent directors in the board can improve the supervision efficiency, reduce possibilities of accounting 
frauds and decrease company earnings management. Lower proportion of independent directors may impair supervision efficiency of the board empowering CEOs to manage earnings freely. As a result, we believe that companies with lower proportion of independent directors in the board run by Cultural Revolution CEOs may notably have less earnings management. We divided full sample into three subsamples according to ratio of independent directors and named subsamples as Group_INDEPEN $=0,1,2$ in ascending order. Results of grouping regressions were showed in Table 4. It can be found that only coefficient of $\mathrm{CR}$ variable in Group_board $=0$ was negatively robust, indicating that companies with less independent directors are more sensible to CEO Cultural Revolution experiences and the inhibit effect is more significant on these companies.

Table 4. Ratio of independent directors affects the correlation between CEO Cultural Revolution experience and corporate earnings management

\begin{tabular}{|c|c|c|c|}
\hline & $\begin{array}{l}\text { absEM } \\
\text { Group_INDEPEN }=0 \\
(1)\end{array}$ & $\begin{array}{l}\text { absEM } \\
\text { Group_INDEPEN }=1 \\
(2)\end{array}$ & $\begin{array}{l}\text { absEM } \\
\text { Group_INDEPEN }=2 \\
(3)\end{array}$ \\
\hline $\mathrm{CR}$ & $\begin{array}{l}-0.061^{*} \\
(-1.85)\end{array}$ & $\begin{array}{l}-0.005 \\
(-1.40)\end{array}$ & $\begin{array}{l}-0.003 \\
(-0.55)\end{array}$ \\
\hline Gender & $\begin{array}{l}0.000 \\
(.)\end{array}$ & $\begin{array}{l}-0.011 \\
(-1.13)\end{array}$ & $\begin{array}{l}0.008 \\
(0.77)\end{array}$ \\
\hline Size & $\begin{array}{l}0.014 \\
(0.64)\end{array}$ & $\begin{array}{l}-0.001 \\
(-0.31)\end{array}$ & $\begin{array}{l}-0.006 \\
(-1.05)\end{array}$ \\
\hline Q & $\begin{array}{l}0.005 \\
(0.44)\end{array}$ & $\begin{array}{l}0.002 \\
(1.04)\end{array}$ & $\begin{array}{l}0.001 \\
(0.28)\end{array}$ \\
\hline ROA & $\begin{array}{l}0.117 \\
(0.64)\end{array}$ & $\begin{array}{l}0.086^{* *} \\
(2.06)\end{array}$ & $\begin{array}{l}0.086+ \\
(1.46)\end{array}$ \\
\hline LEV & $\begin{array}{l}0.156 \\
(1.40)\end{array}$ & $\begin{array}{l}0.043^{* * *} \\
(3.12)\end{array}$ & $\begin{array}{l}0.065^{* * *} \\
(3.83)\end{array}$ \\
\hline ECI & $\begin{array}{l}0.002 \\
(1.18)\end{array}$ & $\begin{array}{l}-0.000 \\
(-0.66)\end{array}$ & $\begin{array}{l}0.000 \\
(1.02)\end{array}$ \\
\hline INDEPEN & $\begin{array}{l}-0.336+ \\
(-1.48)\end{array}$ & $\begin{array}{l}-0.346 \\
(-0.81)\end{array}$ & $\begin{array}{l}-0.059 \\
(-1.23)\end{array}$ \\
\hline DIRECEO & $\begin{array}{l}-0.017 \\
(-0.66)\end{array}$ & $\begin{array}{l}0.001 \\
(0.19)\end{array}$ & $\begin{array}{l}-0.001 \\
(-0.22)\end{array}$ \\
\hline Board & $\begin{array}{l}0.041 \\
(1.41)\end{array}$ & $\begin{array}{l}-0.015 \\
(-0.74)\end{array}$ & $\begin{array}{l}-0.008 \\
(-0.56)\end{array}$ \\
\hline Year & Yes & Yes & Yes \\
\hline Industry & Yes & Yes & Yes \\
\hline _cons & $\begin{array}{l}-0.355 \\
(-0.96)\end{array}$ & $\begin{array}{l}0.239 \\
(1.32)\end{array}$ & $\begin{array}{l}0.195^{* *} \\
(2.30)\end{array}$ \\
\hline $\mathrm{N}$ & 347 & 4670 & 3473 \\
\hline $\mathrm{r} 2$ & 0.208 & 0.040 & 0.044 \\
\hline
\end{tabular}

* Indicates significance at $10 \%$;* significant at $5 \% ; * *$ significant at $1 \%$. Field survey, 2017

The research divided full sample into three subsamples according to ratio of independent directors and named subsamples as Group_INDEPEN=0,1,2 in ascending order. Column 3 was sample with the biggest ratio of independent directors while Column1 was sample with the smallest ratio of independent directors. All regressions included controls for CEO gender, firm size, Tobin's Q, ROA, leverage, equity concentration, ratio of independent directors, board scale and if a CEO is a member of board at the same time. Robust standard errors in parentheses were clustered by firm.

\subsubsection{Company equity concentration affects the correlation between CEO Cultural Revolution} experience and corporate earnings management

According the principal-agent theory, when a listed company has highly concentrated equity structure, the major shareholders of the company dominate the board so they have convenience taking advantage of 
asymmetric information to collude with executives to manage earnings for self-interests (Yang Zhiqiang, Wang Hua, 2014). On the other hand, when shareholding structure is relatively decentralized, the conflict of interests between shareholders and top managers is overbearing because when major and minority shareholders collaborate for common interests, they are well to focus on accounting earnings quality improvement and tend to restrict oversee executives. It has also been proved that company with a better balanced equity structure can more effectively supervise top managers because equivalent shareholding brings every shareholder motivations to oversee executives. Hence, balances concentrated ownership structure has positive correlation to corporate earnings management.

We divided full sample into three subsamples according to company equity concentration and named subsamples as Group_ECI=0,1,2 in ascending order. Results of grouping regressions were showed in Table 5. It can be found that only coefficient of CR variable in Group_ECI $=2$ was negatively robust, indicating that companies with more concentrated equity structure are more sensible to CEO Cultural Revolution experiences and the inhibit effect is more significant on these companies.

Table 5. Company equity concentration affects the correlation between CEO Cultural Revolution experience and corporate earnings management

\begin{tabular}{|c|c|c|c|}
\hline & $\begin{array}{l}\text { absEM } \\
\text { Group_ECI = } 0 \\
(1)\end{array}$ & $\begin{array}{l}\text { absEM } \\
\text { Group_ECI = } 1 \\
(2)\end{array}$ & $\begin{array}{l}\operatorname{absEM} \\
\text { Group_ECI }=2 \\
(3)\end{array}$ \\
\hline $\mathrm{CR}$ & $\begin{array}{l}-0.000 \\
(-0.04)\end{array}$ & $\begin{array}{l}0.003 \\
(0.47)\end{array}$ & $\begin{array}{l}-0.010^{* *} \\
(-2.28)\end{array}$ \\
\hline Gender & $\begin{array}{l}-0.005 \\
(-0.36)\end{array}$ & $\begin{array}{l}-0.009 \\
(-0.55)\end{array}$ & $\begin{array}{l}0.008 \\
(0.54)\end{array}$ \\
\hline Size & $\begin{array}{l}-0.011^{*} \\
(-1.89)\end{array}$ & $\begin{array}{l}-0.004 \\
(-0.55)\end{array}$ & $\begin{array}{l}-0.002 \\
(-0.29)\end{array}$ \\
\hline Q & $\begin{array}{l}0.001 \\
(0.51)\end{array}$ & $\begin{array}{l}0.002 \\
(0.74)\end{array}$ & $\begin{array}{l}0.001 \\
(0.46)\end{array}$ \\
\hline $\mathrm{ROA}$ & $\begin{array}{l}-0.089^{*} \\
(-1.80)\end{array}$ & $\begin{array}{l}0.099 \\
(1.37)\end{array}$ & $\begin{array}{l}0.311^{* * *} \\
(5.55)\end{array}$ \\
\hline LEV & $\begin{array}{l}0.034^{*} \\
(1.70)\end{array}$ & $\begin{array}{l}0.078^{* * *} \\
(4.36)\end{array}$ & $\begin{array}{l}0.063^{* * *} \\
(3.20)\end{array}$ \\
\hline ECI & $\begin{array}{l}-0.001 \\
(-0.79)\end{array}$ & $\begin{array}{l}-0.000 \\
(-0.42)\end{array}$ & $\begin{array}{l}0.001^{* * * *} \\
(2.74)\end{array}$ \\
\hline INDEPEN & $\begin{array}{l}-0.049 \\
(-1.42)\end{array}$ & $\begin{array}{l}-0.041 \\
(-1.26)\end{array}$ & $\begin{array}{l}0.014 \\
(0.35)\end{array}$ \\
\hline DIRECEO & $\begin{array}{l}0.002 \\
(0.54)\end{array}$ & $\begin{array}{l}-0.002 \\
(-0.50)\end{array}$ & $\begin{array}{l}0.005 \\
(1.01)\end{array}$ \\
\hline Board & $\begin{array}{l}0.002 \\
(0.29)\end{array}$ & $\begin{array}{l}-0.008 \\
(-0.86)\end{array}$ & $\begin{array}{l}-0.005 \\
(-0.47)\end{array}$ \\
\hline Year & Yes & Yes & Yes \\
\hline $\begin{array}{l}\text { Industry } \\
\text { _cons }\end{array}$ & $\begin{array}{l}\text { Yes } \\
0.289 * * \\
(2.18)\end{array}$ & $\begin{array}{l}\text { Yes } \\
0.157 \\
(0.84)\end{array}$ & $\begin{array}{l}\text { Yes } \\
-0.042 \\
(-0.31)\end{array}$ \\
\hline $\mathrm{N}$ & 2830 & 2830 & 2830 \\
\hline $\mathrm{r} 2$ & 0.044 & 0.065 & 0.111 \\
\hline
\end{tabular}

* Indicates significance at $10 \% ; * *$ significant at $5 \% ; * * *$ significant at $1 \%$. Field survey, 2017

The research divided full sample into three subsamples according to company equity concentration and named subsamples as Group_ECI=0, 1, 2 in ascending order. Column 3 was sample with the most concentrated equity structure while Column1 was samples with the least concentrated equity structure. All 
regressions included controls for CEO gender, firm size, Tobin's Q, ROA, leverage, equity concentration, ratio of independent directors, board scale and if a CEO is a member of board at the same time. Robust standard errors in parentheses were clustered by firm.

Based on Chapter 4.2, we found that companies with lager board, lower ratio of independent directors and higher concentration ratio of shares are more likely to be influenced by the conservative preferences of CR CEOs. It is because that the principal-agent problems mainly come from conflicts among shareholders, making supervisions of executives by shareholders a more inferior problem, and that gives CEOs more autonomies affecting accounting information quality. These conclusions are cohesive with our hypothesis 3 that companies with less supervision on CEOs empowering a CEO more autonomies to affect accounting earnings quality are well influenced by Cultural Revolution CEOs' conservative decision-making preferences.

\subsection{Effects of Earnings Management Levels on the Correlation Between CEO Cultural Revolution Experience and Corporate Earnings Management}

For most companies, the optimal operating strategy is to properly manage earnings. Since it is hard to act proactively to discipline managers, only when earnings management is so aggressive that shareholders' interests are well impaired, CEOs who aggressively manage earnings may be disciplined, punished or even forcibly dismissed (Sonali Hazarika et al, 2012). As a result, when a corporate manages earnings too aggressively, its CEO may have so limited influence on corporate behaviors that his risk preference cannot affect corporate earnings management efficiently. It is understandable that only when a company manages earnings within reason, a Cultural Revolution CEO has available autonomies to significantly inhibit corporate earnings management.

We divided full sample into four subsamples according to earnings management levels and named subsamples as Group_EM=0, 1, 2, 3 in ascending order. Results of grouping regressions were showed in Table 6. It can be found that only coefficient of CR variable in Group_EM $=2$ was negatively robust, indicating that companies whose earnings management levels were within an relatively high but controllable range were more sensible to CEO Cultural Revolution experiences and the inhibit effect was more significant on these companies.

Table 6. Corporate earnings management level affects the correlation between CEO Cultural Revolution experience and corporate earnings management

\begin{tabular}{|c|c|c|c|c|c|c|c|c|}
\hline & $\begin{array}{c}\text { absEM } \\
(1) \\
\text { Group }\end{array}$ & $\mathrm{EM}=0$ & $\begin{array}{l}\text { absEM } \\
(2) \\
\text { Group }\end{array}$ & $\mathrm{EM}=1$ & $\begin{array}{l}\text { absEM } \\
(3) \\
\text { Group }\end{array}$ & $\mathrm{EM}=2$ & $\begin{array}{l}\text { absEM } \\
(4) \\
\text { Group }\end{array}$ & $\mathrm{EM}=3$ \\
\hline $\mathrm{CR}$ & $\begin{array}{l}-0.000 \\
(-0.52)\end{array}$ & & $\begin{array}{l}-0.001 \\
(-1.22)\end{array}$ & & $\begin{array}{l}-0.002^{* *} \\
(-2.01)\end{array}$ & & $\begin{array}{l}-0.003 \\
(-0.42)\end{array}$ & \\
\hline Gender & $\begin{array}{l}0.002 \\
(0.73)\end{array}$ & & $\begin{array}{l}-0.001 \\
(-1.07)\end{array}$ & & $\begin{array}{l}-0.006 * * \\
(-2.07)\end{array}$ & & $\begin{array}{l}-0.019 \\
(-1.25)\end{array}$ & \\
\hline Size & $\begin{array}{l}-0.000 \\
(-0.25)\end{array}$ & & $\begin{array}{l}0.001 \\
(1.09)\end{array}$ & & $\begin{array}{l}-0.001 \\
(-1.17)\end{array}$ & & $\begin{array}{l}0.006 \\
(1.25)\end{array}$ & \\
\hline Q & $\begin{array}{l}0.000 \\
(0.82)\end{array}$ & & $\begin{array}{l}0.000 \\
(1.06)\end{array}$ & & $\begin{array}{l}0.000 \\
(1.27)\end{array}$ & & $\begin{array}{l}-0.001 \\
(-0.42)\end{array}$ & \\
\hline ROA & $\begin{array}{l}-0.003 \\
(-0.46)\end{array}$ & & $\begin{array}{l}0.002 \\
(0.29)\end{array}$ & & $\begin{array}{l}-0.012 \\
(-1.39)\end{array}$ & & $\begin{array}{l}0.229^{* * *} \\
(4.83)\end{array}$ & \\
\hline LEV & $\begin{array}{l}0.001 \\
(0.83)\end{array}$ & & $\begin{array}{l}0.001 \\
(0.68)\end{array}$ & & $\begin{array}{l}0.005+ \\
(1.59)\end{array}$ & & $\begin{array}{l}0.075^{* * *} \\
(4.52)\end{array}$ & \\
\hline ECI & $\begin{array}{l}-0.000 \\
(-0.62)\end{array}$ & & $\begin{array}{l}-0.000 \\
(-0.02)\end{array}$ & & $\begin{array}{l}-0.000 \\
(-0.25)\end{array}$ & & $\begin{array}{l}0.001^{* * *} \\
(2.78)\end{array}$ & \\
\hline INDEPEN & $\begin{array}{l}-0.002 \\
(-0.48)\end{array}$ & & $\begin{array}{l}-0.003 \\
(-0.64)\end{array}$ & & $\begin{array}{l}-0.005 \\
(-0.55)\end{array}$ & & $\begin{array}{l}-0.080+ \\
(-1.57)\end{array}$ & \\
\hline DIRECEO & $\begin{array}{l}-0.000 \\
(-0.46)\end{array}$ & & $\begin{array}{l}0.001 \\
(1.05)\end{array}$ & & $\begin{array}{l}-0.002^{* *} \\
(-2.03)\end{array}$ & & $\begin{array}{l}0.001 \\
(0.11)\end{array}$ & \\
\hline
\end{tabular}




\begin{tabular}{|c|c|c|c|c|}
\hline Board & $\begin{array}{l}0.001+ \\
(1.46)\end{array}$ & $\begin{array}{l}-0.000 \\
(-0.29)\end{array}$ & $\begin{array}{l}0.004^{* *} \\
(2.10)\end{array}$ & $\begin{array}{l}0.004 \\
(0.31)\end{array}$ \\
\hline Year & Yes & Yes & Yes & Yes \\
\hline Industry & Yes & Yes & Yes & Yes \\
\hline _cons & $\begin{array}{l}0.012 \\
(1.00)\end{array}$ & $\begin{array}{l}0.020 \\
(1.38)\end{array}$ & $\begin{array}{l}0.088^{* * *} \\
(4.31)\end{array}$ & $\begin{array}{c}-0.062 \\
(-0.52)\end{array}$ \\
\hline $\mathrm{N}$ & 2122 & 2123 & 2122 & 2123 \\
\hline $\mathrm{r} 2$ & 0.024 & 0.029 & 0.044 & 0.110 \\
\hline
\end{tabular}

The research divided full sample into four subsamples according to earnings management levels and named subsamples as Group_EM=0, 1, 2, 3 in ascending order. Column 4 was sample with the biggest earnings management degree while Column1 was sample with the smallest earnings management degree. All regressions included controls for CEO gender, firm size, Tobin's Q, ROA, leverage, equity concentration, ratio of independent directors, board scale and if a CEO is a member of board at the same time. Robust standard errors in parentheses were clustered by firm.

\subsection{Effects of Earnings Management Directions on the Correlation Between CEO Cultural Revolution Experience and Corporate Earnings Management}

William Scott (1996) divided earnings management that affects income statement into 4 types. Firstly, companies overestimate current spending in order to conceal actual income and magnify losses when they are in corporate distress. Secondly, underestimation of income exists when companies want to avoid political costs and taxes by lowering accounting income. Thirdly, in consideration of bonus policy and cost of liabilities executives are liable to recognize revenue in advance or increase discretional accruals to inflate current incomes. Fourthly, companies may smooth incomes based on earning expectation. Since we used Jones model (Dechow et al., 1995) to calculate absolute value of discretionary accruals (absEM) which indicated corporate earnings management degree, to explore whether different earnings management directions may affect the correlation between CEO Cultural Revolution experience and corporate earnings management, we divided full sample into two subsamples according to earnings management directions.

As showed in Table 7 column (1) and (2), CEO's Cultural Revolution experience had diverse impact on corporate positive and negative earnings management. Coefficient of $\mathrm{CR}$ variable on negative earnings management was significantly negative indicating that CEOs who suffered Cultural Revolution in the youth were reluctant to undertake downward earnings management. According to the classification of earnings management mentioned above, one of the most noticeable purposes for downward earnings management is to avoid political costs and taxes. The enterprise income tax system was reformed in 2007 and the real tax rate for a great number of listed companies was changed. Under the circumstances, how did the change of real tax rate affect Cultural Revolution CEOs earnings management behavior? Literatures have argued that companies choose earnings management types according to change tendency of expected tax rate. Corporate expecting real tax rate to decline are apt to manage earnings downward and manage earnings upward if expected tax rate increase(Wang Yuetang et al, 2009; Li Zengfu, Dong Zhiqiang, Lian Yujun, 2011). We aimed to find out if Cultural Revolution CEOs were specifically cautious toward earnings management to avoid taxes. Hence, we added dummy two variables, TaxTreat and Tax, representing the direction of real tax rate change in 2007 in order to test if real tax rate change affected Cultural Revolution CEOs' performance on inhibiting corporate earnings management. The TaxTreat variable was assigned 0 for the year of 2007 and before and 1 for the year of 2008 and after. The Tax variable was assigned $-1,0$ and 1 to respectively indicated a company's real tax rate declined, fixed or increased after income tax system reformation.

Results in column (3) of Table 7 showed that for companies whose tax rate declined, the change of tax rate significantly affected corporate earnings management which was coincided with conclusions of existing literatures (Wang Yuetang et al,2009; Li Zengfu et al,2011). The coefficient of CR variable was significantly negative and that of TaxTreat variable was insignificantly positive, which mean that companies experiencing tax rate increases did not noticeably elevate earnings management levels and Cultural Revolution CEOs' inhibition of downward aggressive earnings management may be one of the reasons. 
Table 7. Corporate earnings management directions affect the correlation between CEO Cultural Revolution experience and corporate earnings management

\begin{tabular}{|c|c|c|c|c|c|}
\hline & $\begin{array}{c}\text { absEM } \\
\text { EM>0 } \\
(1)\end{array}$ & $\begin{array}{c}\text { absEM } \\
\text { EM<0 } \\
(2)\end{array}$ & $\begin{array}{l}\text { absEM } \\
\text { Tax }=-1 \\
(3)\end{array}$ & $\begin{array}{c}\text { absEM } \\
\text { Tax }=0 \\
(4)\end{array}$ & $\begin{array}{c}\text { absEM } \\
\text { Tax }=1 \\
(5)\end{array}$ \\
\hline $\mathrm{CR}$ & $\begin{array}{l}0.002 \\
(0.37)\end{array}$ & $\begin{array}{l}-0.006^{*} \\
(-1.66)\end{array}$ & $\begin{array}{l}-0.003 \\
(-1.02)\end{array}$ & $\begin{array}{l}-0.001 \\
(-0.14)\end{array}$ & $\begin{array}{l}-0.018^{* *} \\
(-2.17)\end{array}$ \\
\hline TaxTreat & & & $\begin{array}{l}-0.020^{* * *} \\
(-4.84)\end{array}$ & $\begin{array}{l}-0.012 \\
(-0.83)\end{array}$ & $\begin{array}{l}0.016 \\
(1.34)\end{array}$ \\
\hline Gender & $\begin{array}{l}0.005 \\
(0.51)\end{array}$ & $\begin{array}{l}-0.010 \\
(-1.03)\end{array}$ & $\begin{array}{l}-0.010 \\
(-1.35)\end{array}$ & $\begin{array}{l}0.022 \\
(0.60)\end{array}$ & $\begin{array}{l}0.005 \\
(0.22)\end{array}$ \\
\hline Size & $\begin{array}{l}0.003 \\
(0.62)\end{array}$ & $\begin{array}{l}-0.002 \\
(-0.55)\end{array}$ & $\begin{array}{l}-0.001 \\
(-0.25)\end{array}$ & $\begin{array}{l}-0.005 \\
(-0.72)\end{array}$ & $\begin{array}{l}0.002 \\
(0.18)\end{array}$ \\
\hline Q & $\begin{array}{l}-0.002 \\
(-1.11)\end{array}$ & $\begin{array}{l}0.004^{* *} \\
(2.48)\end{array}$ & $\begin{array}{l}0.002 \\
(1.17)\end{array}$ & $\begin{array}{l}-0.001 \\
(-0.30)\end{array}$ & $\begin{array}{l}0.006+ \\
(1.48)\end{array}$ \\
\hline ROA & $\begin{array}{l}0.610^{* * *} \\
(12.20)\end{array}$ & $\begin{array}{l}-0.199^{* * *} \\
(-5.10)\end{array}$ & $\begin{array}{l}0.095^{* *} \\
(2.47)\end{array}$ & $\begin{array}{l}-0.000 \\
(-0.00)\end{array}$ & $\begin{array}{l}0.024 \\
(0.25)\end{array}$ \\
\hline LEV & $\begin{array}{l}0.048^{* * * *} \\
(3.27)\end{array}$ & $\begin{array}{l}0.041^{* * * *} \\
(3.33)\end{array}$ & $\begin{array}{l}0.042^{* * *} \\
(4.29)\end{array}$ & $\begin{array}{l}0.051^{*} \\
(1.72)\end{array}$ & $\begin{array}{l}0.081^{* * *} \\
(2.86)\end{array}$ \\
\hline ECI & $\begin{array}{l}0.000 \\
(1.35)\end{array}$ & $\begin{array}{l}0.000^{*} \\
(1.79)\end{array}$ & $\begin{array}{l}0.000 \\
(0.99)\end{array}$ & $\begin{array}{l}-0.000 \\
(-0.47)\end{array}$ & $\begin{array}{l}0.000 \\
(0.24)\end{array}$ \\
\hline INDEPEN & $\begin{array}{l}-0.041 \\
(-1.34)\end{array}$ & $\begin{array}{l}-0.006 \\
(-0.20)\end{array}$ & $\begin{array}{l}-0.033 \\
(-1.40)\end{array}$ & $\begin{array}{l}-0.149^{* *} \\
(-2.67)\end{array}$ & $\begin{array}{l}-0.076 \\
(-1.17)\end{array}$ \\
\hline DIRECEO & $\begin{array}{l}0.005+ \\
(1.49)\end{array}$ & $\begin{array}{l}-0.003 \\
(-1.29)\end{array}$ & $\begin{array}{l}-0.000 \\
(-0.08)\end{array}$ & $\begin{array}{l}-0.001 \\
(-0.21)\end{array}$ & $\begin{array}{l}-0.009^{* *} \\
(-2.04)\end{array}$ \\
\hline Board & $\begin{array}{l}-0.006 \\
(-0.72)\end{array}$ & $\begin{array}{l}0.003 \\
(0.56)\end{array}$ & $\begin{array}{l}-0.002 \\
(-0.31)\end{array}$ & $\begin{array}{l}0.003 \\
(0.28)\end{array}$ & $\begin{array}{l}-0.010 \\
(-0.66)\end{array}$ \\
\hline Year & Yes & Yes & Yes & Yes & Yes \\
\hline Industry & Yes & Yes & Yes & Yes & Yes \\
\hline _cons & $\begin{array}{l}-0.076 \\
(-0.63)\end{array}$ & $\begin{array}{l}0.122 \\
(1.36)\end{array}$ & $\begin{array}{l}0.087 \\
(1.13)\end{array}$ & $\begin{array}{l}0.269^{*} \\
(1.74)\end{array}$ & $\begin{array}{l}0.024 \\
(0.11)\end{array}$ \\
\hline $\mathrm{N}$ & 3763 & 4727 & 6797 & 380 & 841 \\
\hline Within r2 & 0.169 & 0.085 & 0.038 & 0.099 & 0.100 \\
\hline
\end{tabular}

* Indicates significance at $10 \% ;{ }^{* *}$ significant at $5 \% ; * * *$ significant at $1 \%$.Field survey, 2017

Column 1 was sample with positive earnings management behaviors and Column 2 was sample with negative earnings management behaviors. The TaxTreat variable was assigned 0 for the year of 2007 and before and 1 for the year of 2008 and after. The Tax variable was assigned $-1,0$ and 1 respectively indicating that a company's real tax rate was declined, fixed or increased after income tax system reformation. All regressions included controls for CEO gender, firm size, Tobin's Q, ROA, leverage, equity concentration, ratio of independent directors, board scale and if a CEO is a member of board at the same time. Robust standard errors in parentheses are clustered by firm.

\subsection{Degree of CEOs' Involvement in Cultural Revolution Affects Correlation Between CEO Cultural Revolution Experience and Corporate Earnings Management}

Whether different degrees of involvement in Cultural Revolution decide CEO attitude toward corporate earnings management? We included a variable (GA) representing the area of a CEO's graduation college which was manually collected from companies' reports and CEOs' resumes. In the period of Cultural Revolution Chinese political center was in northern China, according to which we assume that the closer to northern China the greater a province was involved and impact by the revolution. Therefore we took the area of a CEO's graduation school as an indicator of where he/she lived in the youth and hence represented the degree of his/her involvement in the revolution. Provinces where CEOs' graduated were divided into 5 
Table 9. Degree of CEOs' involvement in Cultural Revolution affects the correlation between CEO Cultural Revolution experience and corporate earnings management

\begin{tabular}{|c|c|c|}
\hline & $\begin{array}{l}\text { absEM (all) } \\
(1)\end{array}$ & $\begin{array}{l}\text { absEM (main sector) } \\
(2)\end{array}$ \\
\hline $\mathrm{CR}$ & $\begin{array}{l}-0.017 \\
(-1.34)\end{array}$ & $\begin{array}{l}-0.034^{* *} \\
(-2.33)\end{array}$ \\
\hline c.CR\#c.GA & $\begin{array}{l}0.003 \\
(0.75)\end{array}$ & $\begin{array}{l}0.009^{*} \\
(1.65)\end{array}$ \\
\hline GA & $\begin{array}{l}-0.003 \\
(-0.85)\end{array}$ & $\begin{array}{c}-0.000 \\
(-0.03)\end{array}$ \\
\hline Gender & $\begin{array}{l}-0.011 \\
(-0.82)\end{array}$ & $\begin{array}{l}0.001 \\
(0.19)\end{array}$ \\
\hline Size & $\begin{array}{l}0.002 \\
(0.46)\end{array}$ & $\begin{array}{l}0.002 \\
(1.51)\end{array}$ \\
\hline Q & $\begin{array}{l}0.003^{* * *} \\
(2.70)\end{array}$ & $\begin{array}{l}0.047 \\
(1.49)\end{array}$ \\
\hline $\mathrm{ROA}$ & $\begin{array}{l}0.023 \\
(0.83)\end{array}$ & $\begin{array}{l}0.064^{* * *} \\
(4.17)\end{array}$ \\
\hline LEV & $\begin{array}{l}0.039^{* * *} \\
(3.11)\end{array}$ & $\begin{array}{l}0.000^{*} \\
(1.70)\end{array}$ \\
\hline ECI & $\begin{array}{l}0.000 \\
(1.58)\end{array}$ & $\begin{array}{l}0.064^{*} \\
(1.66)\end{array}$ \\
\hline INDEPEN & $\begin{array}{l}0.009 \\
(0.27)\end{array}$ & $\begin{array}{l}-0.000 \\
(-0.03)\end{array}$ \\
\hline DIRECEO & $\begin{array}{l}-0.001 \\
(-0.38)\end{array}$ & $\begin{array}{l}-0.004 \\
(-0.46)\end{array}$ \\
\hline Board & $\begin{array}{l}0.003 \\
(0.51)\end{array}$ & $\begin{array}{l}-0.034^{* *} \\
(-2.33)\end{array}$ \\
\hline Year & Yes & Yes \\
\hline Industry & Yes & Yes \\
\hline _cons & $\begin{array}{l}-0.011 \\
(-0.13)\end{array}$ & $\begin{array}{l}0.014 \\
(0.14)\end{array}$ \\
\hline $\mathrm{N}$ & 2801 & 2165 \\
\hline r2 & 0.049 & 0.050 \\
\hline
\end{tabular}

* Indicates significance at $10 \%$;** significant at $5 \% ; * * *$ significant at $1 \%$. Field survey,2017

Variable GA represented areas of CEOs' graduation colleges which were manually collected from companies' reports and CEOs' resumes. Provinces where CEOs' graduated were divided into 5 areas which were northeast China, north China, east China, mid China and south, west China. Variable GA was set and assigned 1-5 to represent the 5 areas orderly and to indicate degrees of revolution involvement in descending order. Column 2 used samples of main sector which was the subsample consisted of the 4 main industries which included about $78.7 \%$ of all companies and its statistic traits were in accordance with that of full samples from the cohorts 2005-2014. All regressions included controls for CEO gender, firm size, Tobin's Q, ROA, leverage, equity concentration, ratio of independent directors, board scale and if a CEO was a member of board at the same time.

\section{Conclusion}

Cultural Revolution experienced CEOs have a significant negative impact on company earnings management levels. In the control of the CEO's political background and the enterprise state-owned property factors, the negative influence is still very significant. For state-owned enterprises, the Cultural Revolution CEO's negative influence on company's earnings management is greater. Combined with the feature of structure of the board of directors, we found that with a larger scale of board of directors, lower 
proportion of independent directors and higher percentage of shareholding of the top ten shareholders, the negative influence of Cultural Revolution CEO on company earnings management is more obvious. It means that the larger a Cultural Revolution CEO's autonomy on company's financial information quality, the more significant Cultural Revolution CEO's influence on company's earnings management behavior.

The earnings management level also has influence on the behavior of Cultural Revolution experiences CEO. According to the results, except the case when earnings management level is too low and too high, when the company earnings management level is in a high controllable scope, the Cultural Revolution experiences CEO can significantly reduce the company's earnings management level. When it comes to Cultural Revolution CEO's influence on different direction of earnings management, the results showed that the Cultural Revolution CEO have a robust inhibiting effect on negative earnings management. As one of the main motivations of corporate negative earnings management is to avoid tax, this paper further studies the influence of different direction of tax rate change on the relationship between CEO and enterprise earnings management. Results showed that the earnings management level of the company with lower tax rate is significantly reduced, and the influence of the Cultural Revolution CEO on earnings management is not significant. When tax increases, earnings management level does not change significantly, but the CEO has significant inhibition effect on earnings management of the Cultural Revolution, showing that the reason why higher tax rate does not significantly lead to higher level of earnings management is because the Cultural Revolution CEO's cautious attitude and inhibition on radical negative direction of earnings management.

To explore the possible cause of earnings management behavior of Cultural Revolution CEO, we found that the degree of CEO's involvement of Cultural Revolution affected the degree of earnings management decrease. The deeper a CEO is influenced by the Cultural Revolution, the greater the company's earnings management will reduce.

\section{References}

1. Alesina, Alberto, Nicola Fuchs-Schündeln. 2005. The Effect of Communism on People's Preferences, National Bureau of Economic Research.

2. Ali, Ashiq, Weining Zhang. 2015. Ceo Tenure and Earnings Management. Journal of Accounting and Economics, 59(1), 60-79.

3. B. A. v. d. Kolk, O. v. d. Hart and J. Burbridge.1995.Approaches to the Treatment of PTSD.Harvard Medical School,

4. Beneish, Messod D., Mark E. Vargus. 2002. Insider Trading, Earnings Quality, and Accrual Mispricing. Accounting Review, 77(4), 755-91.

5. Benmelech, Efraim, Carola Frydman. 2015. Military Ceos. Journal of Financial Economics, 117(1), 43-59.

6. Bertrand, Marianne. 2003. Managing with Style: The Effect of Managers on Firm Policies. Quarterly Journal Of Economics, 118(4), 1169-208.

7. Boshier, R.; Y. Huang; Q. H. Song, L. Song. 2006. Market Socialism Meets the Lost Generation: Motivational Orientations of Adult Learners in Shanghai. Adult Education Quarterly, 56(3), 201-22.

8. Chatterjee Arijit, Donald C. Hambrick. 2007. It's All About Me: Narcissistic Chief Executive Officers and Their Effects on Company Strategy and Performance. Administrative Science Quarterly, 52(3), 351-86.

9. Chen yanyan, Luo danglun. 2012. Change of local officials and enterprise investment. Economic research, (s2), $18-30$.

10.Cronqvist, Henrik; Alessandro Previtero; Stephan Siegel, Roderick E. White. 2014. The Fetal Origins Hypothesis in Finance__ Prenatal Environment and Financial Risk Taking.

11.Davis, L, L. J. Siegel. 2000. Posttraumatic Stress Disorder in Children and Adolescents: A Review and Analysis. Clinical Child \& Family Psychology Review, 3(3), 135-54.

12.Giuliano, P., A. Spilimbergo. 2014. Growing up in a Recession. Review Of Economic Studies, 81(2), 787-817.

13.Graham, John R., Krishnamoorthy Narasimhan. 2004. Corporate Survival and Managerial Experiences During the Great Depression. Ssrn Electronic Journal, 200 (Pt 23)(23), 3021-31.

14.Hambrick. Donald C., Sydney Finkelstein. 1987. Managerial Discretion: A Bridge between Polar Views of Organizational Outcomes. Research in Organizational Behavior, 9(4), 369-406.

15.Hazarika, Sonali; Jonathan M. Karpoff, Rajarishi Nahata. 2012. Internal Corporate Governance, Ceo Turnover, and Earnings Management. Journal of Financial Economics, 104(1), 44-69. 
16. He Fan; Zhang xinzhe, Zheng jun.2015.Background characteristics and accounting information quality of Ceo power. Journal of zhongnan university of economics and law, (5), 108-16.

17. J. P. Danthine and J. B. Donaldson.1990.Risk Sharing, the Minimum Wage and the Business Cycle.42:133-138

18. Jiang, Fuxiu; Bing Zhu, Jicheng Huang. 2013. Ceo's Financial Experience and Earnings Management Journal of Multinational Financial

19. Karpoff, Jonathan M., Gerald S. Martin. 2008. The Cost to Firms of Cooking the Books. Journal of Financial \& Quantitative Analysis, 43(3), 581-611.

20. KAUSTIA, MARKKU, SAMULI KNUPFER. 2008. Do Investors Overweight Personal Experience-Evidence from Ipo Subscriptions. THE JOURNAL OF FINANCE, LXIII(6), 2679-702.

21. Kendler, K. S.; K Sheth; C. O. Gardner, Prescott Ca. 2002. Childhood Parental Loss and Risk for First-Onset of Major Depression and Alcohol Dependence: The Time-Decay of Risk and Sex Differences. Psychological Medicine, $32(7), 1187-94$.

22. Krosnick, Jon A. 1989. Attitude Importance and Attitude Accessibility. Personality \& Social Psychology Bulletin, 15(3), 297-308.

23. Li chunli. 2012. The reasons for the participation of Hong Kong youth in the "new social movement". Journal of guangzhou socialist college, (3), 64-67.

24. Li peigong, xiao min.2012. Ceo tenure and enterprise capital investment. Financial research, (2), 127-41..

25. Li ting, zhu xiongzhao. 2009. Early experience of epigenetic mechanisms affecting behavior of individuals in adulthood. Advances in psychological science, 17(6), 1274-80.

26. Li zengfu; Dong zhiqiang, Lian yujun. 2011. Accrual project earnings management or real activity surplus? Research on income tax reform in China in 2007. Management of the world, (1), 121-34.

27. Liao puming.2011. Empirical research on the characteristics and earnings management of CEO change directors. Statistics and decisions, 16:14, 6-149.

28. Liao xiaoping, Chen jianyue. 2006. Basic characteristics of youth values. Journal of China youth political college, (4), 40-44.

29. Lin kuangzheng. 2010. Post-80s movement.

30. Liu huilong, Wang chengfang and Wu liansheng.2014. Decision-making power configuration _ earnings management and investment efficiency. Economic research,93-106.

31. Luo jinbo. 2016. Institutional investors, Ceo political association and earnings management. Accounting and economic research.

32. Main, M.; N. Kaplan, J. Cassidy. 1985. Security in Infancy, Childhood, and Adulthood: A Move to the Level of Representation. Monographs of the Society for Research in Child Development, 50(1/2), 66-104.

33. Malmendier, U., S. Nagel. 2011. Depression Babies: Do Macroeconomic Experiences Affect Risk Taking? Quarterly Journal Of Economics, 126(1), 373-416.

34. P. M. Dechow, R. G. Sloan and A. P. Hutton.1994.Detecting Earnings Management. Social Science Electronic Publishing,70:193-225

35. Richard Flacks. 1989. Youth and social change.

36. Rijsenbilt, Antoinette, Harry Commander. 2013. Narcissus Enters the Courtroom: Ceo Narcissism and Fraud. Journal of Business Ethics, 117(2), 413-29.

37. Schoar, Antoinette, Luo Zuo. 2011. Shaped by Booms and Busts: How the Economy Impacts Ceo Careers and Management Styles. Nber Working Papers, (49).

38. Schoar, Antoinette. 2007. Ceo Careers and Style

39. Shen weitao, Yu xiaoyu. 2014. Ceo's early life experience and corporate investment behavior. Based on the three difficult years of Ceo's early experience. Economic management, 36(12), 72-82.

40. Shi Kan. 2010. Disaster psychology. Science press.

41. Su dongwei, Lin dapang. 2010. Equity incentive _ earnings management and corporate governance. Economic research, 11, 88-100.

42. Ting, Irene Wei Kiong; Noor Azlinna Binti Azizan, Long Kweh Qian. 2015. Upper Echelon Theory Revisited: The Relationship between Ceo Personal Characteristics and Financial Leverage Decision. Procedia - Social and Behavioral Sciences, 195, 686-94.

43. V. Covello and P. Sandman.2001.Risk Communication: Evolution and Revolution.

44. Wang yuetang, Wang liangliang and Gong caiping.2009. Income tax reform _ earnings management and economic 
consequences. Economic research,86-98.

45. Weng youwei. 1997. Discussion on the social trends during the "Cultural Revolution" and the anthology of "social history and social change of China in the 20th century".

46. Yang zhiqiang, Wang hua. 2014. Internal compensation gap, equity concentration and earnings management behavior - based on the comparison analysis of salary between senior management team and employees. Accounting research, (6), 57-65.

47. Ye sheng wen, Ye wangchunzi. 2014. Ceo power, environmental uncertainty and earnings management. Accounting and economic research.

48. Zhang guohua; Chen fangzheng.2006. Empirical research on the correlation between earnings management and board characteristics of listed companies in China. Research on technology economy and management,42-44.

49. Zhang Yijie; Wang yan, Tang yuanhu. 2006. Empirical research on the relationship between board characteristics and earnings management of listed companies. Management review, 18(3), 14-19.

50. Zhao minwei, Yan yanyang. 2015. Manager's early famine experience and corporate financial policy. Southern economy, (10), 49-63.

51. Zhejiang Youth League School research group.2004. Youth and social thought research.

52. Zheng danniang; Zhang sumin.2013.The social unrest and youth work: a review of youth issues in foreign social unrest. Chinese youth studies, (11), 107-12. 